\title{
Schwann Cells Induce Sprouting in Motor and Sensory Axons in the Adult Rat Spinal Cord
}

\author{
Ying Li and Geoffrey Raisman \\ Norman and Sadie Lee Research Centre, Laboratory of Neurobiology, National Institute for Medical Research, London \\ NW7 1AA, United Kingdom
}

\begin{abstract}
Circumscribed lesions were made within either the corticospinal tract or the ascending dorsal column tracts at the upper cervical level in adult rats. The responses of the tract axons were studied by orthograde transport from injections of horseradish peroxidase or biocytin. At $2 \mathrm{~d}$, the ends of the cut axons were swollen, and the lesions induced en passant varicosities in the adjacent uncut axons. Although there have been reports of retraction, we found that even after several weeks, large numbers of cut axons still persisted in the central lesion area (where there was complete tissue destruction and intense macrophage infiltration), and also in the adjacent regions of the tract. The cut ends were expanded into a variety of shapes-large, complex, bulbous, and recurved-and many had profuse local branches with or without small, terminal-type varicosities.
\end{abstract}

A suspension of Schwann cells cultured from neonatal sciatic nerve was injected by a minimally traumatic air pressure microinjection technique so as to form a bolus, comparable in size to the lesions, in either the corticospinal or the ascending dorsal column tracts at the upper cervical level. Despite previous findings that corticospinal axons do not elongate into peripheral nerve grafts, we found that both corticospinal and ascending dorsal column axons sprouted in response to contact with the transplanted Schwann cells. The response to the Schwann cells was much more rapid than to the lesions. By $2 \mathrm{~d}$, in both descending and ascending tracts, both the axons that had been severed at the time of injection and also the adjacent uncut axons had already given rise to the branches that (unlike the localized sprouting seen after the long-term lesions) extended for considerable distances parallel to and fasciculating with each other and with the uncut tract axons. In addition, a mass of fine, tortuous, varicose branches invaded the superficial parts of the Schwann cell grafts, where they formed arborizations with small bead-like expansions resembling presynaptic boutons; as in their normal terminal fields, the arborizations

Received Oct. 18, 1993; revised Jan. 19, 1994; accepted Jan. 27, 1994

Y.L. was funded by the International Spinal Research Trust. We are grateful for the help and advice of Dr. Pauline Field. Schwann cells were provided by Dr. Jean Lawrence. We thank Norman and Sadie Lee and Peter Banyard for their encouragement.

Correspondence should be addressed to G. Raisman, Laboratory of Neurobiology, National Institute for Medical Research, The Ridgeway, Mill Hill, London NW7 1AA, UK.

Copyright (c) 1994 Society for Neuroscience $0270-6474 / 94 / 144050-14 \$ 05.00 / 0$ formed by the corticospinal axons were smaller and finer than those formed by the ascending axons.

[Key words: Schwann cell, transplant, spinal cord, axon regeneration, tracts, repair, spinal lesion, glial pathways]

Peripheral nerve grafts are able to induce growth of cut central axons and direct the growing sprouts to distant terminal ficlds where they can make structural and functional synaptic connections with appropriate targets (Berry et al., 1988a; Carter et al., 1989; Keirstead et al., 1989; Thanos, 1991, 1992; Campbell et al., 1992; Knoops et al., 1993). There are a number of limitations to this approach. Apart from the inevitable mechanical damage caused by the physical insertion of the nerve, the most favorable grafts pick up only a proportion of the host fibers, the axons leaving the grafts show only restricted penetration of the central target tissues (Vidal-Sanz et al., 1987, 1991), and in some cases abnormal connections may be formed (Zwimpfer et al., 1992). The grafts are selective for certain categories of axons (Benfey et al., 1985; Morrow et al., 1993), and other types of axons (such as the corticospinal tract; Richardson et al., 1982, 1984) may not respond.

Spinal cord injury is one of the clearest indications for tract repair; the scrious and currently irreparable functional effects are due to disconnection of neurons from their targets by lesions of axons in the long spinal fiber tracts. Even if the above limitations could be overcome, peripheral nerve "bridges" would not offer a complete solution to spinal tract lesions: the long ascending and descending spinal tracts recruit axons from many different sites, at all levels of the brain and spinal cord, and deliver them to targets that are no less dispersed. Therefore, it is not practically possible to devise peripheral nerve bridges that would selectively reconnect all the different components of such a dispersed system of connections. Repair would occur only if, after bridging the lesion, the regenerating axons were able to regrow correctly along their normal trajectories. Thus, to be effective, the bridge must pick up axons from different sources, convey them across the lesion, and then allow the different groups of axons to reenter the host tracts and complete the remainder of their courses through those tracts.

Until recently, it was considered that adult central tracts were impenetrable to the growth of axons (Ramon y Cajal, 1928). In the last few years, however, two types of evidence have suggested that this is not the case. Schwab and colleagues have provided evidence that antibodies neutralizing the effect of a central myelin-associated molecule allow cut adult axons to regenerate along myelinated fiber tracts (Schnell and Schwab, 1993; Schwab et al., 1993). Wictorin and colleagues have provided evidence 

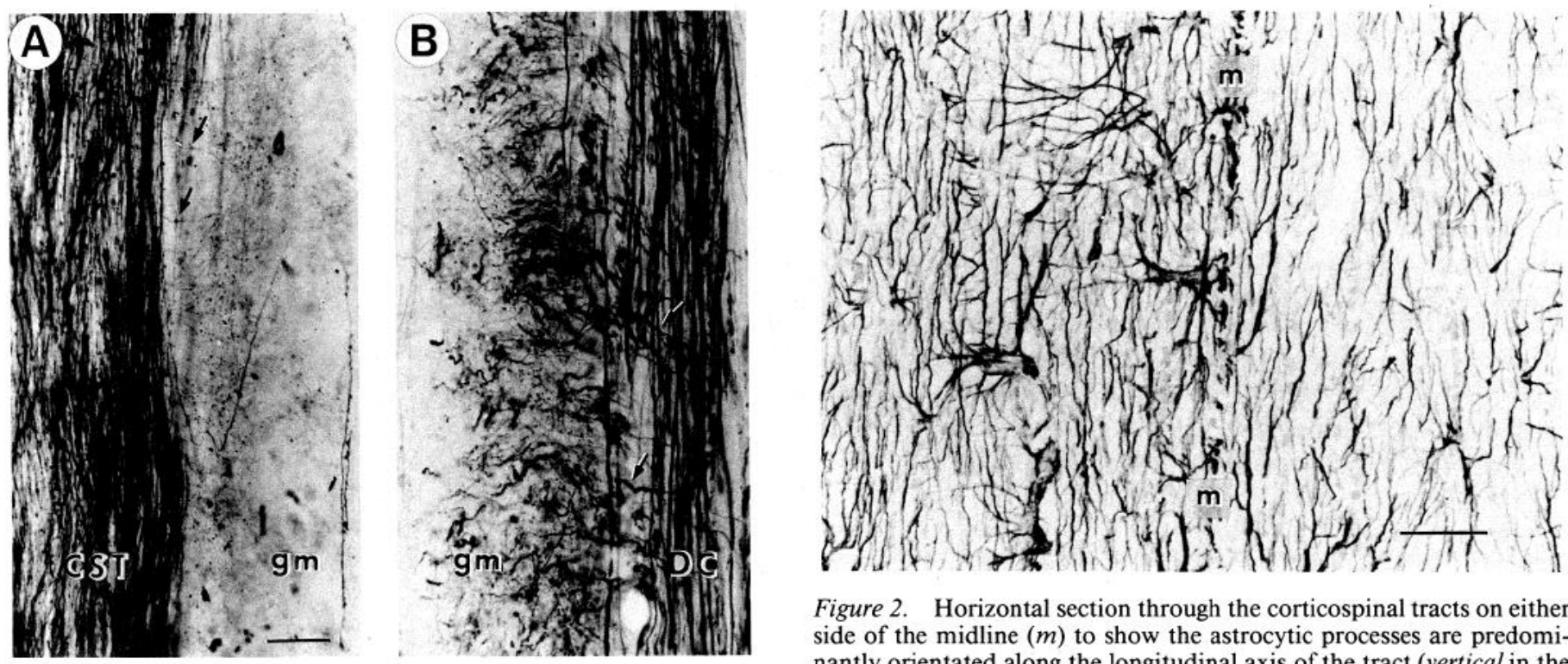

Figure 2. Horizontal section through the corticospinal tracts on either side of the midline $(\mathrm{m})$ to show the astrocytic processes are predominantly orientated along the longitudinal axis of the tract (vertical in the picture). Section was immunostained for GFAP, which is heavier on the left side due to a Schwann cell transplant placed about $2 \mathrm{~mm}$ rostral to the level of the picture. The transverse astrocytic processes (mainly seen toward the midline on the left) form a rectilinear network with longitudinal processes. Scale bar, $25 \mu \mathrm{m}$.

that transplanted embryonic neurons can grow axons along adult myelinated fiber tracts to reach their normal terminal fields and make synapses there (Wictorin et al., 1990a,b, 1991, 1992).

Experiments from our group have shown that small quantities of embryonic neurons "microtransplanted" by a minimally traumatic method (Emmett et al., 1990) rapidly grow axons along otherwise undamaged adult host tracts (Davies et al., 1993), and the axon growth is strictly in alignment with the longitudinal axis formed by the axons and longitudinal astrocytic processes of the host tract (Davies et al., 1994). Using a mouse neuronspecific monoclonal antibody (Lund et al., 1985), we have examined the projections of embryonic mouse hippocampal neurons microtransplanted into both the corticospinal and ascending dorsal column tracts of adult rat spinal cord ( $\mathrm{Li}$ and Raisman, 1993). In both tracts donor axons grew rapidly along the longitudinal axis of the host tract in both rostral and caudal directions (see also Wictorin and Björklund, 1992). Thus, both the long motor and sensory myelinated adult intraspinal tracts, whose damage causes such devastating effects in human injury, are permissive for growth, at least from embryonic axons.

Studies from our laboratory have shown that the glial cells of central myelinated tracts form a regular rectilinear skeleton $(\mathrm{Su}-$ zuki and Raisman, 1992). The astrocytes generate a parallel array of fine, untapering longitudinal processes, which may be important as a pathway for the growth of the axons of the microtransplanted embryonic neurons (Davies et al., 1994). The trauma of inserting peripheral nerve grafts would cause considerable gliosis and scarring (Reier, 1986), which would have the effect of distorting and "closing" such glial pathways through the tracts.

Since the "axogenic" effects of peripheral nerve grafts depend on the presence of viable Schwann cells in the nerve (Berry et al., 1988a,b; Smith and Stevenson, 1988; Hagg et al., 1991; Paino and Bunge, 1991), a number of workers have investigated the transplantation of cultured Schwann cells (Wrathall et al., 1984; Kromer and Cornbrooks, 1985; Kuhlengel et al., 1990a; 
Figure 3. A, Silver staining of axons (Palmgren method) to show the typical size and location of a lesion in the corticospinal tract. Arrows, swellings at the ends of cut axons at $18 \mathrm{hr}$ po. $B$, A beam of descending HRP-filled CST axons partially cut $(c)$ by a lesion (Les) and partially passing uncut $(u)$ beside the lesion. Varicosities are present at the ends of the cut axons (e.g., v), and also on the uncut passing axons (e.g., arrow). The mass of dark cells in the lower part of the lesion are red blood cells. Four days po. Scale bars, $100 \mu \mathrm{m}$.
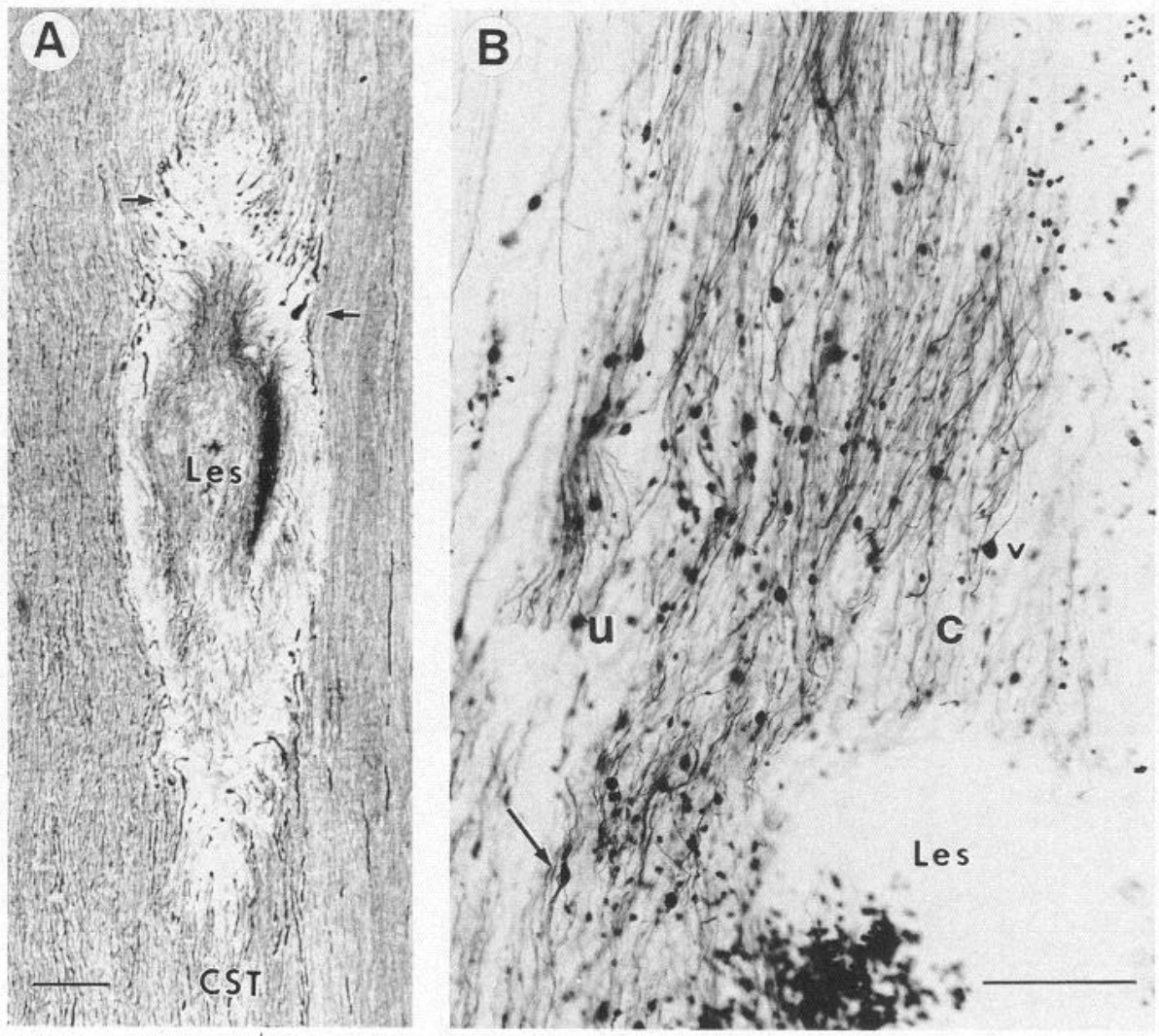

Martin et al., 1991, 1993; Paino and Bunge, 1991; MonteroMenei et al., 1992; Neuberger et al., 1992). In the present study, we have attempted to decrease further the operative damage by using an air pressure delivery technique (Emmett et al., 1990) to microtransplant small volumes of a suspension of cultured peripheral nerve Schwann cells through a stereotaxically guided glass micropipette (Brook et al., 1993) into circumscribed locations in the corticospinal or ascending dorsal column tracts in adult rats.

Most previous studies of spinal axon regeneration have been based either on retrograde cell labeling (e.g., Richardson et al., $1982,1984)$, which is suitable only if the axons have traveled for some distance from the lesion in a peripheral nerve or other transplant, or on axon identification by immunohistochemistry (Martin et al., 1991, 1993), or by orthograde labeling (Schnell and Schwab, 1993) with the tetramethylbenzidine reaction for horseradish peroxidase (HRP). These techniques are not suitable for revealing the fine details of the response of the sprouting axons at the lesion/transplant site, especially combined with the disorganization caused by traumatic lesion and transplant techniques. In the present study we have used orthograde transport of HRP to identify the descending and ascending axons. By using the glucose oxidase detection method, we have been able to obtain complete pictures of the responses of the cut and uncut axons in the relatively normal tract environment around microlesion sites, and therefore to reexamine the apparent failure of corticospinal axons to respond to Schwann cells in peripheral nerve grafts (Richardson et al., 1982, 1984).

The ultimate interest in the peripheral nerve/Schwann cell transplantation approach is as a possible method for obtaining functionally useful long spinal axon regeneration in human par- aplegic patients. An important issue, therefore, is whether the cut axons persist long enough at the lesion site for them to be stimulated to regenerate by therapeutic interventions. Some experimental observations have suggested that cut axons undergo a retrograde axonal degeneration leading to their retraction from the lesion site (Kalil and Schneider, 1975; Lahr and Stelzner, 1990; Firkins et al., 1993). In the present study our combination of a microlesion/microtransplantation approach, which causes minimal disturbance to the adjacent host tract architecture, and a precise orthograde axon label has enabled us to reevaluate the question of whether cut adult corticospinal axons can persist in a lesioned area, and whether they can sprout in response to contact with Schwann cells.

\section{Materials and Methods}

Schwann cells were obtained from sciatic nerves of $2 \mathrm{~d}$ postnatal rats of a locally inbred AS strain by a modification (Brook et al., 1993) of the method of Brockes et al. (1979) and maintained in culture for about 1 week. In some samples, the numbers of fibroblasts were reduced by complement-mediated killing.

Schwann cells were suspended at a concentration of $1-2 \times 10^{7} / \mathrm{ml}$ in a defined medium, and drawn up into a fire-polished glass micropipette of internal diameter about $70 \mu \mathrm{m}$. In adult female rats (190-230 gm body weight) under intraperitoneal tribromoethanol anesthesia $(20 \mathrm{mg} /$ $100 \mathrm{gm}$ body weight), the dorsal surface of the spinal cord was exposed at the level of the first two cervical segments and a stereotaxic micromanipulator was used to insert the micropipette slightly to one side of the midline to a depth of $0.4-0.5 \mathrm{~mm}$ (for the ascending dorsal column tracts, 11 animals) or $0.7-0.8 \mathrm{~mm}$ (for the corticospinal tracts, 31 animals). Cell suspension (1-1.5 $\mathrm{l}$ ) was injected using a solenoid-driven air pressure system (Emmett et al., 1990) over a period of about $2 \mathrm{~min}$.

For making tract lesions (41 animals), an insulated stainless steel electrode was inserted into the same positions and a constant anodal DC current of $10 \mu \mathrm{A}$ was passed for 4-7 min. Recovery was rapid, with 

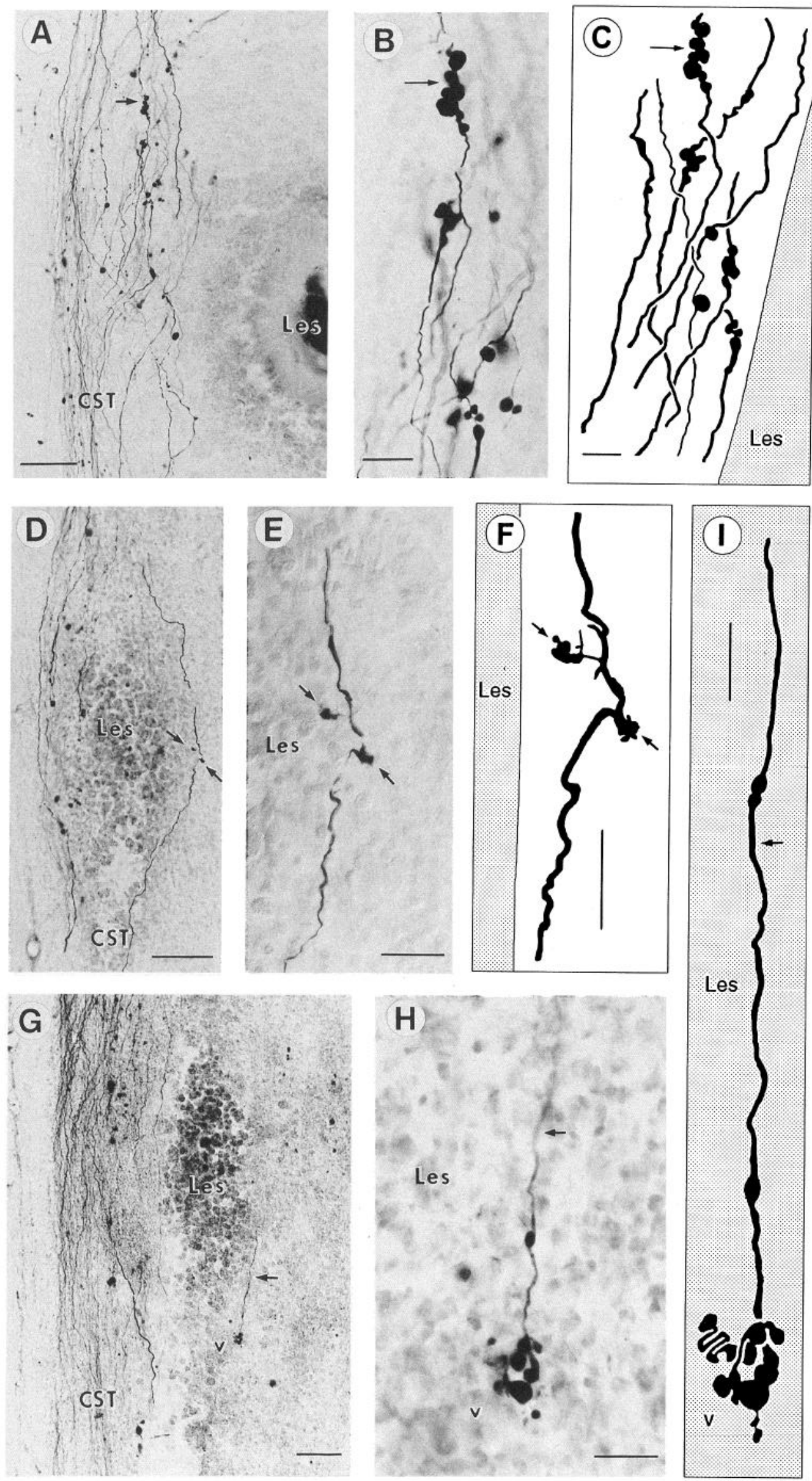

Figure 4. $A, B$ (photomicrographs), and $C$ (camera lucida drawing) show contiguous clusters of axon varicosities (e.g., arrow) in the uncut CST axons adjacent to a long-term (16 d) lesion. $D, E$ (photomicrographs), and $F$ (camera lucida drawing) show that a longterm (45 d) lesion stimulates (probably nodal) coarse, irregular, short sprouts (arrows) from an adjacent uncut CST axon. $G, H$ (photomicrographs), and $I$ (camera lucida drawing) show the multiple varicosities $(v)$ and recurved segments at the expanded cut end of a CST axon (arrow) that persists in the entirely destroyed, macrophage-invaded area of a long-term (38 d) lesion. Scale bars: $A$, $D, G, 100 \mu \mathrm{m}$; remainder, $25 \mu \mathrm{m}$. 


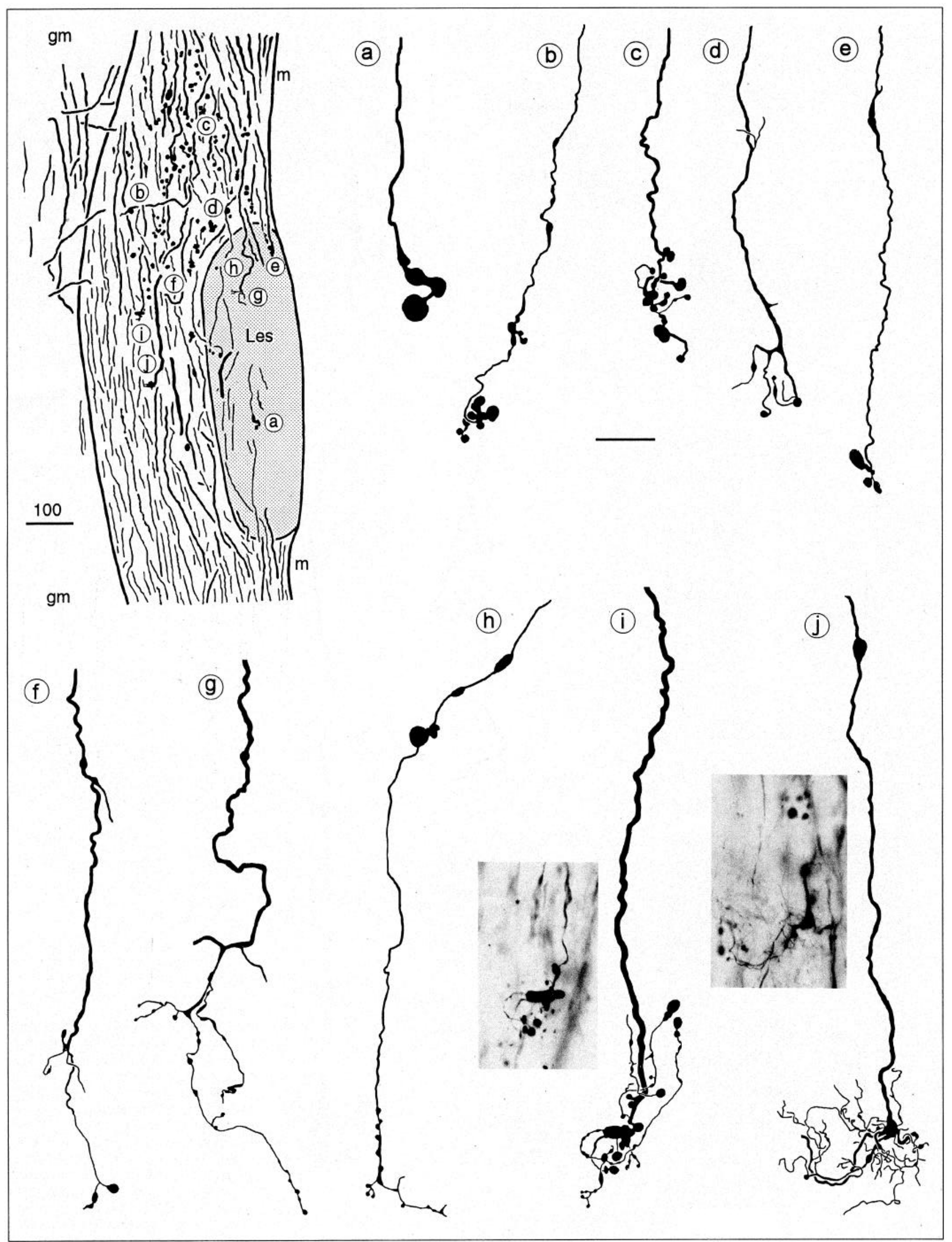


the animals showing no functional deficits or abnormalities in their normal cage behavior.

Forty to forty-eight hours before death the descending corticospinal axons (31 animals with Schwann cell grafts, 32 with lesions alone, and 5 normal animals) were labeled by two adjacent stereotaxic injections each of about $0.2 \mu \mathrm{l}$ of $40 \%$ Sigma type VI horseradish peroxidase (HRP) in saline or $5 \%$ biocytin in saline over $5 \mathrm{~min}$ into the pyramidal tract on one side of the midline at the base of the medulla. The ascending dorsal column axons ( 11 animals with Schwann cell grafts, 9 with lesions alone, and 5 normal animals) were labeled by similar injections of HRP into the dorsal column to a depth of $0.4-0.6 \mathrm{~mm}$ below the dorsal surface of the spinal cord, to one side of the midline at one to two vertebral segments below the graft or lesion level.

In a preliminary series of experiments we had applied the HRP to the frontal cortex (i.e., at the level of the cell bodies of origin of the corticospinal tract) and detected the orthogradely labeled axons by the sensitive tetramethylbenzidine method. Unfortunately, the large crystals of reaction product completely obscured the fine details of the axonal arborizations. Using the more gentle glucose oxidase method enabled us to see the axonal arborizations, but the lower sensitivity of detection was unsuitable for such long axon transport, and we found that we could get detectable terminal labeling only by applying the tracer to the corticospinal tract axons at the medullary level, much closer to the site of the transplants.

For similar reasons, and also to enable us to label more axons than would be convenient by exposing large numbers of individual dorsal root ganglia, the orthograde label was also applied to the ascending dorsal column tracts rather than to the cells of origin.

After $2 \mathrm{~d}$ to 6 weeks, the animals were deeply anesthetized with Sagatal and perfused through the heart with $100 \mathrm{ml}$ of saline followed by either a mixture of $1 \%$ paraformaldehyde and $2 \%$ glutaraldehyde (for HRP) in $0.1 \mathrm{M}$ phosphate buffer $(\mathrm{PB})$ at $\mathrm{pH} 7.3-7.4$ for $30 \mathrm{~min}$ at $4^{\circ} \mathrm{C}$, or (for biocytin) $2 \%$ paraformaldehyde and $1 \%$ glutaraldehyde in $\mathrm{PB}$, followed by $10 \%$ sucrose in PB for $30 \mathrm{~min}$ at $4^{\circ} \mathrm{C}$. Serial frozen $60-100 \mu \mathrm{m}$ horizontal sections through the entire transplant or lesion area were collected floating in PB.

HRP was detected by the glucose oxidase method (Itoh et al., 1979), and biocytin by an overnight incubation in Vector ABC solution in 0.1 M phosphate-buffered saline (PBS) at $4^{\circ} \mathrm{C}$, followed by $1 \mathrm{hr}$ PBS wash, and then detection by the glucose oxidase method. Sections were mounted on gelatin-coated slides, air dried at room temperature for $5-10 \mathrm{hr}$, and then counterstained with $1 \%$ aqueous neutral red, dehydrated, cleared with Histoclear, and mounted in a mixture of dibutyl phthalate, polystyrene, and Histoclear (DPH).

To monitor the lesion procedure, animals were killed after $4-18 \mathrm{hr}$, and serial horizontal $20 \mu \mathrm{m}$ cryostat sections were stained by the method of Palmgren (1960). For astrocytes, $10 \mu \mathrm{m}$ unfixed cryostat sections were immunostained for glial fibrillary acidic protein as in Davies et al. (1994). To identify the transplanted Schwann cells, $10 \mu \mathrm{m}$ unfixed cryostat sections were immunostained for low-affinity nerve growth factor receptor immunohistochemistry (as in Brook et al., 1993), but using 1:100 of clone 192 anti-ral nerve growth factor receptor monoclonal antibody (Boehringer, Mannheim) as the primary antibody.

\section{Results}

\section{Normal material}

In both descending and ascending tracts the majority of the axons were of uniform diameter, unbranched, and parallel to each other (Fig. 1 $A, B$ ). Sometimes an axon showed an isolated, single ovoid varicosity. Occasional fine axons had small, regularly spaced varicosities. Where the axons branched, the branches arose at right angles and turned laterally across the tract to reach terminal fields in the adjacent spinal gray matter. In other cases the entire axon turned laterally to leave the tract and enter the terminal field.
The preterminal parts of the corticospinal axons (Fig. $1 A$; see also Fig. $10 \mathrm{~A}, \mathrm{C}$ ) generally left the tract in a caudolateral direction. Those terminating in the immediately adjacent medial part of the spinal gray matter bore a small cluster of rounded presynaptic boutons near their ends. In some cases, a subsidiary cluster of terminals was produced about 50-200 $\mu \mathrm{m}$ before the termination. The preterminal parts of the ascending dorsal column axons also turned sharply laterally, with an ascending inclination, into the gray matter of the dorsal horn (Fig. $1 B, C$ ) where they could be very tortuous, with branches and varicosities. The finest branches frequently consisted of short dichotomous terminal segments directed caudally, and ending in a series of two or three small round presynaptic boutons.

Horizontal sections immunostained with glial fibrillary acidic protein (GFAP) showed that both the ascending dorsal columns and the descending corticospinal tracts (Fig. 2) had a rectilinear skeleton of longitudinal and transverse astrocytic processes generated by solitary astrocytes interposed in the rows of contiguous tract oligodendrocytes in a similar manner to that described in the fimbria (Suzuki and Raisman, 1992). The arrangement of the astrocytes was similar in the descending and ascending tracts, but with major differences in size: the astrocytes associated with the finer, corticospinal axons were small and delicate, and those associated with the wider ascending sensory tract axons were conspicuously larger, with coarser processes.

\section{Lesions}

The DC current produced small, compact, ovoid lesions of around $0.5-1.0 \mathrm{~mm}$ diameter and around $1 \mathrm{~mm}$ in length (Fig. $3 A$ ) and localized to either the descending corticospinal tract or the ascending dorsal columns. The center of the lesion consisted of an area of total destruction, which became filled by debris and exudate, and populated by macrophages (e.g., Fig. $4 D, G$ ).

For the first $2 \mathrm{~d}$ after the operation, injections of HRP were unsatisfactory for demonstrating the cut ends of the axons. (This was a mechanical problem associated with the frozen sectioning; the fluid-engorged lesion area was so fragile that the large, dense axon swellings attached to their parent stems could not be preserved.) Palmgren staining at this time showed that the ends of the cut axons at the edge of the lesions were swollen (Fig. 3A). This effect was most marked with the proximal stumps, attached to the cell bodies, that is, at the rostral edge of the lesion for the descending fibers, and the caudal edge for the ascending fibers. At $4 \mathrm{~d}$, HRP labeling confirmed that both cut and uncut axons expanded into varicosities (Fig. $3 B$ ).

Over the period from 2 to 6 weeks after the operation, for a distance of up to $200 \mu \mathrm{m}$ on either side of the lesion center, axons en passant developed characteristic strings of contiguous spherical varicosities (Fig. $4 A-C$ ), a configuration never seen in normal material or in tracts with Schwann cell grafts (see below). Uncut axons passing in direct contact with the lesion center were strongly stimulated, and gave rise to short, club-like sprouts (Fig. $4 D-F$ ).

Considerable numbers of completely severed axons remained in the lesion area. These severed axons showed progressively increasing swelling and/or sprouting at their cut ends (Fig. 4G-

Figure 5. Top left, Low-power camera lucida drawing (scale bar, $100 \mu \mathrm{m}$ ) of a lesion of the CST (survival $45 \mathrm{~d}$ ) to show the location of the various cut axon endings illustrated in $a-j$ (scale bar, $25 \mu \mathrm{m}$ ). The endings in $a, e, g$, and $h$ are in the entirely destroyed, macrophage-invaded area (Les); the remainder, although also belonging to cut axons, lie within an area of diffuse axon damage in the adjacent CST, which still contains an array of parallel uncut axons and presumably intact astroglial organization. Photomicrographs are included for $i$ and $j$. 

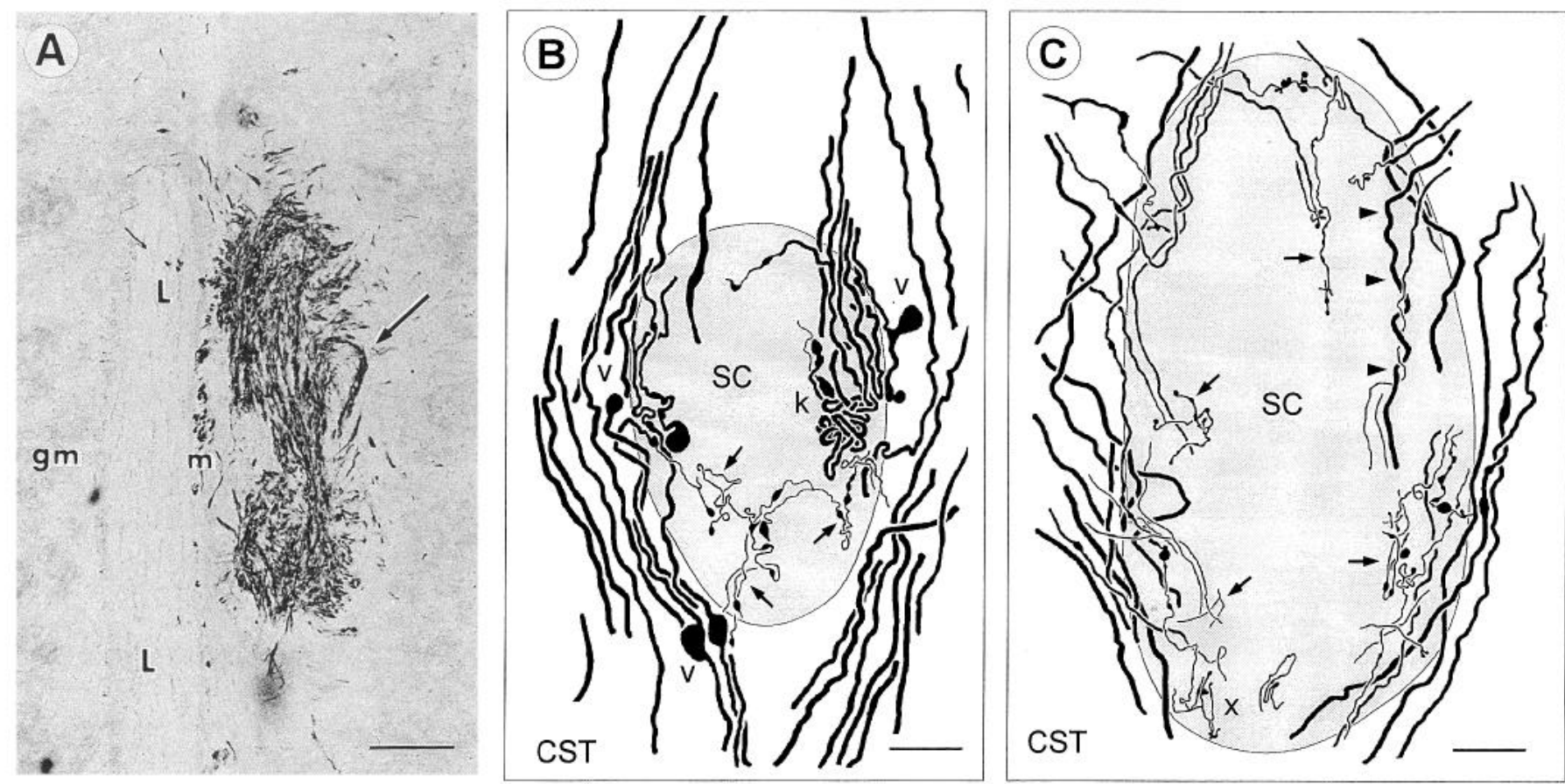

Figure 6. A, Mass of Schwann cells transplanted into the upper cervical level of the right CST, immunostained for low-affinity nerve growth factor receptor. Arrow, typical perivascular flare of Schwann cells leaving the graft to ensheathe a blood vessel (cf. Brook et al., 1993). L, left CST. Seven days po. $B$, Camera lucida drawing of CST axons to show varicosities $(v)$, a knot-like mass of tortuous segments $(k)$, and fine terminal plexus-like extensions (arrows) into the Schwann cell transplant. Five days po. Color photograph is shown in Figure $11 B$. $C$, Camera lucida drawing to show the invasion of the superficial area of a Schwann cell graft by fine, terminal plexus-like axons (arrows; $X$ is shown enlarged in Fig. 10B,D). Arrowheads, a bundle of uncut CST axons crossing the surface of the graft. Eight days po. Scale bars: $A, 200 \mu \mathrm{m} ; B$ and $C, 25 \mu \mathrm{m}$.

I). These effects were seen prominently in the descending corticospinal tracts and also, although less markedly, in the ascending dorsal column tracts. The cut axons had long, uniformdiameter segments that could be followed for $0.5-1 \mathrm{~mm}$ toward the lesion. During this part of their course they were straight, and showed almost no indication of damage (or an occasional single varicosity) until they terminated abruptly, either within the macrophage-filled area of the lesion center or in the surrounding tract (Figs. $4 G-I, 5$ ). The cut ends did not appear to have retracted; some may have advanced a short distance into the macrophage area. The cut ends showed a variety of morphologies, but there was no obvious relationship between the location of the cut endings and the form of the ending.

Many of the large- and small-diameter axons terminated in
Figure 7. Camera lucida drawings of HRP-labeled CST axons in Schwann cell grafts in the CST at $5 \mathrm{~d}$ po $(A)$ and $8 \mathrm{~d}$ po $(B, C)$. $A$, A CST axon $(x)$ whose main stem $(s)$ gives rise to a fine, parallel varicose branch (arrows). B, A fine CST axon (presumed newly formed) with small varicosities gives rise to a knot-like segment $(k)$ from which arises a small, stalked, preterminal boutonlike structure $(x)$ before continuing as a fine straight segment $(p)$ parallel to a large (presumed uncut) CST axon with large varicosities. $C$, A varicose CST axon gives rise (arrow) to several branches with a strong tendency to fasciculate $(f)$. Scale bars, $25 \mu \mathrm{m}$.

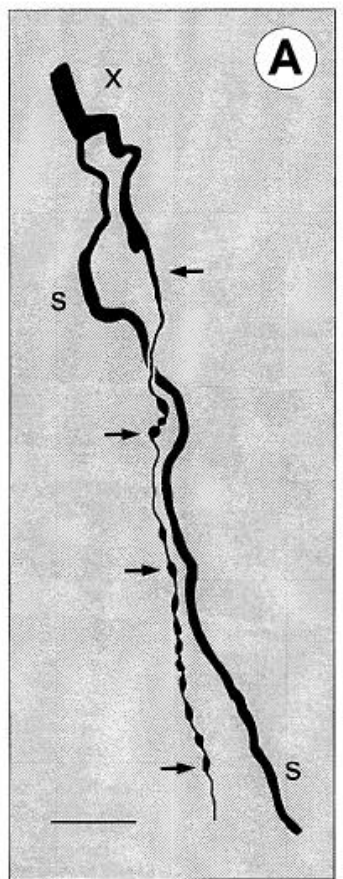

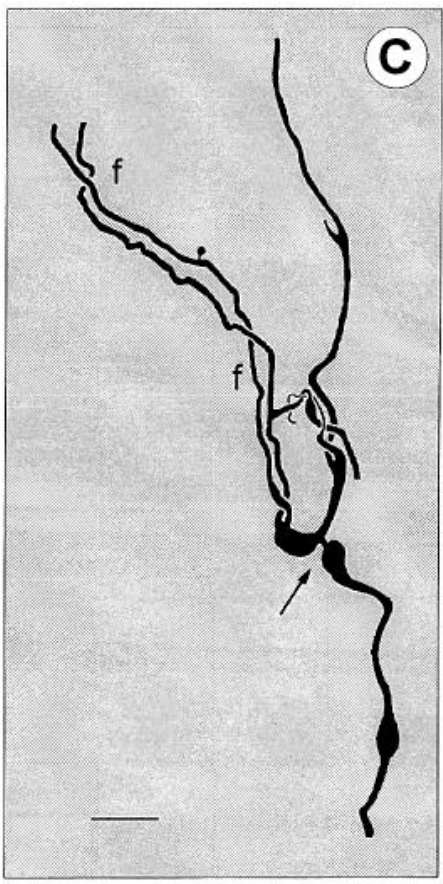



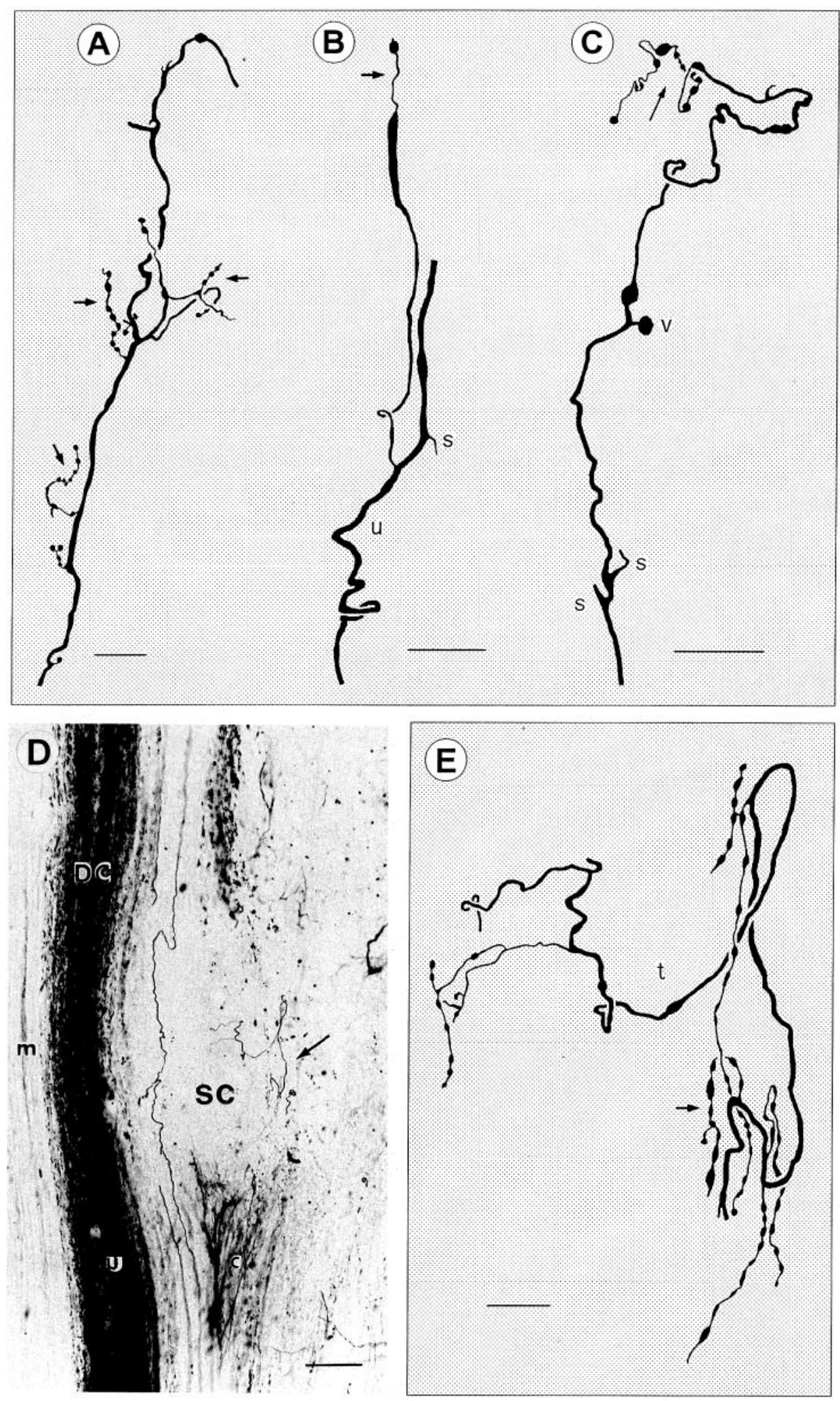

Figure 8. $A-E$, Morphological stages of axon growth of ascending DC axons in Schwann cell grafts. $A$ and $C$. Six days po; $B, D$, and $E, 13 \mathrm{~d}$. $A$, Cut end showing multiple varicose branching (arrows). B, Probable uncut axon $(u)$ with a short, spur-like branch $(s)$ and a long parallel (presumed newly formed) branch ending in a narrow segment (arrow) bearing a small terminal varicosity. $C, \mathrm{~A}$ cut ascending axon with two short, spur-like branches $(s)$ and a shortstalked varicosity $(v)$ progressively narrows into a fine, increasingly tortuous and varicose terminal segment (arrow) ending in a small varicosity. $D$, Dorsal columns. Medially is a dense band of HRP-labeled, uncut axons $(u)$; laterally, a band of axons cut $(c)$ by the Schwann cell transplant $(S C)$ gives rise to a multiply branched axonal sprout (arrow). $E$, Camera lucida drawing of the sprouting axon from $D$ to show transverse turning $(t)$ and varicose dichotomous branching (e.g., arrow). Scale bars, $A-C$ and $E, 25 \mu \mathrm{m} ; D, 100 \mu \mathrm{m}$. a mass of large varicosities, connected by very short, narrow segments (Fig. $5 b, e$ ), and often characteristically recurved configurations (Fig. $4 G-I$ ), which never occurred in the tracts with Schwann cell grafts. In other cases, the cut ends were only slightly expanded, but gave rise to a profusion of fine sprouts that formed arborizations, exceeding $50 \mu \mathrm{m}$ across, in the region of the cut axonal end (Fig. $5 c, i, j)$. Some axonal arborizations were threadlike and nonvaricose, ending freely (Fig. $5 j$ ), while others bore small, spherical varicosities, en passant or terminal, resembling the presynaptic boutons in terminal fields (Fig. $5 c, d, i$ ).

Although the profuseness of the terminal branching in the long-term lesions exceeded that seen in any case with Schwann 
Figure 9. A, A bundle of CST axons gives rise to three fine, tortuous varicose axons (arrow) that loop into the surface of a Schwann cell graft at $5 \mathrm{~d}$ po. $B$, A single, uncut CST axon gives rise to a multiply varicose segment $(v)$ that loops into the surface of an adjacent Schwann cell graft at $8 \mathrm{~d}$ po. $C$, Camera lucida drawing of a terminal plexus-like array $(x)$ of fine, tortuous, varicose axons [one of which (arrow) is a branch of an apparently uncut CST axon] invading the surface of a Schwann cell graft at $5 \mathrm{~d}$ po. Scale bars, $25 \mu \mathrm{m}$.
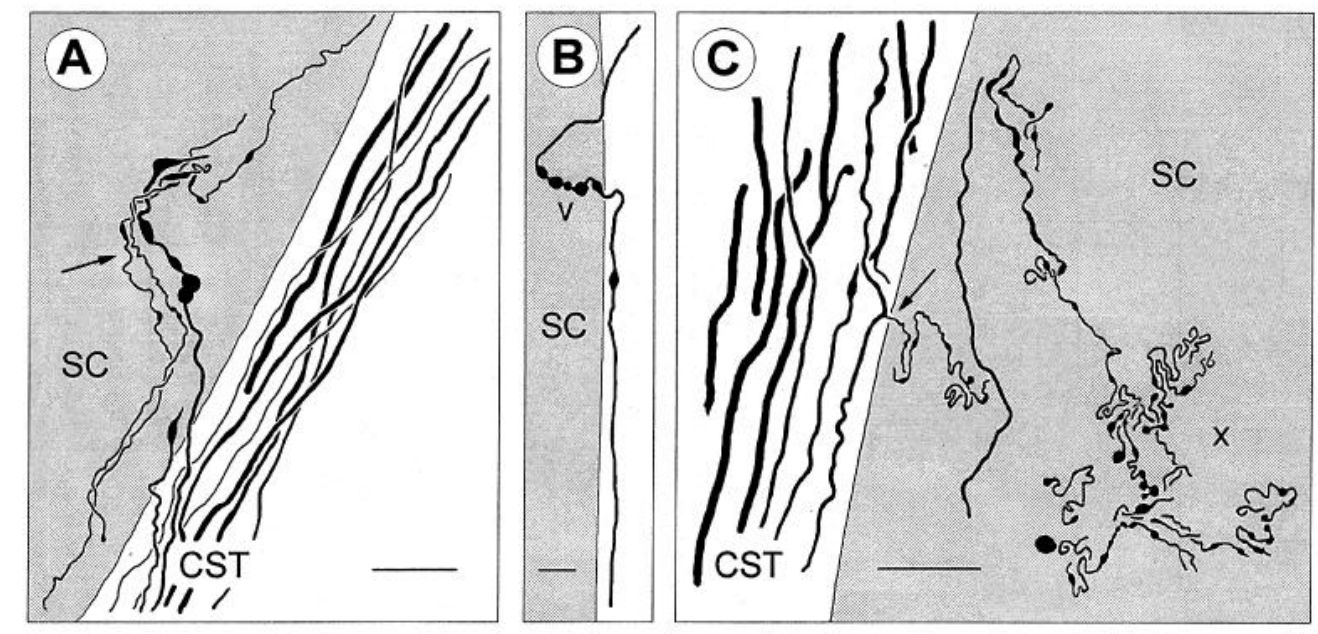

cell transplants, the terminal branches in the long-term lesions did not extend for more than $100-150 \mu \mathrm{m}$ (Fig. $5 f-h$ ), and never for such long distances as the axon branches seen in the tracts with Schwann cell grafts (below).

\section{Schwann cell transplants}

The microinjection of Schwann cells both introduces donor cells into the host tracts, and also damages a number of host axons at the injection site. The transplanted Schwann cells formed ovoid masses (e.g., see Figs. 6, 11) of around $0.5-1.0 \mathrm{~mm}$ diameter and around $1 \mathrm{~mm}$ length in either the corticospinal or the ascending dorsal column tracts. Immunoreactivity for lowaffinity nerve growth factor receptor showed that the Schwann cells of the central cell cluster migrated as cuffs along the blood vessels of the transplant region, and individual Schwann cells detached themselves from the transplant mass and migrated as ribbon-like cells in parallel with the longitudinal axis of the host fiber tracts (as shown by Brook et al., 1993, in the fimbria).

The most striking axonal responses to the Schwann cell grafts were at the interface with the host tract tissue. Host tract axons and finer axonal branches penetrated for a short distance (up to $200 \mu \mathrm{m}$ ) into the Schwann cell masses, but did not reach the center of the larger grafts (e.g., compare Fig. 6B,C).

The Schwann cell grafts affected cut axons, but also many of the effects were en passant responses in axons assumed to be uncut, because they continued unbroken through the host tract beyond the transplant region (e.g., see Figs. 9B, 11A). Both descending and ascending axons responded to Schwann cells. In both cut and uncut host axons, the Schwann cell transplants induced (1) branching (Fig. 7A,C), (2) reorientation (loops and tortuosity), and (3) changes in diameter (narrowing and varicosities; Fig. 7A).

Branching. Branching occurred very rapidly. It was well established by $2 \mathrm{~d}$ after transplantation (the earliest time point studied, since $48 \mathrm{hr}$ was allowed for orthograde transport of the HRP tracer). Axons could give rise to one or a number of branches (Fig. $7 A, C$ ). Where multiple, the branch points were usually separated by $50-100 \mu \mathrm{m}$ segments of unbranched parent axon, suggesting that the sprouts might be arising at the nodes of Ranvier of the myelinated axons (e.g., Fig. $8 A$; Tomatsuri et al., 1993). The branches were usually associated with varicosities or tortuosity of the parent axon, and could be small, short spurs (Figs. $7 C, 8 B, C$ ) or at least $100 \mu \mathrm{m}$ long (e.g., Fig. 7); even longer branches may have been formed, but would not have been contained even in the $100-\mu \mathrm{m}$-thick sections used for this study. In many cases the axons narrowed, or the branches were very fine (e.g., Fig. 8), and second- and third-order branching occurred (e.g., Figs. $7 C, 8 E$ ).

The initial orientation of the branches tended to follow the direction of the parent axon, that is, caudally for the descending axons (Fig. 7A) and rostrally for the ascending axons (Fig. 8B). After some initial searching about, all axon segments tended to take up a longitudinal rostrocaudal arrangement, and branches from a single parent stem often fasciculated closely with each other (e.g., Fig. $7 C$ ), with the parent axon, and with other adjacent axons, and presumably in parallel with the longitudinal astrocytic processes of the host tract glial skeleton (Fig. 2; Davics et al., 1994). The wider-diameter ascending dorsal column axons produced larger arborizations (Fig. $8 D, E$; see also Fig. $11 C, D$ ) than the finer, descending corticospinal axons (e.g., Fig. 6B,C).

Reorientation (loops and knots). Segments from uncut axons in the host tract looped into the Schwann cell transplants, passed through them, and returned again to continue their caudal course in the host tract (Fig. 9A,B; see also Fig. 11A). These segments often showed many varicosities, although (unlike the long-term lesion effect described below) the varicosities were separate from each other. Very fine axons often made multiple local changes of direction, so that they formed knot-like segments (Fig. 7B) before taking up a final, straight course, parallel to the rostrocaudal longitudinal axis of the tract.

Changes in diameter (narrowing and varicosity). Axons narrowed down to very fine segments that formed a terminal-like plexus in the Schwann cell grafts (Figs. $6 C, 9 C$ ). The branched terminal segments were very tortuous, with many tiny varicosities, similar to the presynaptic boutons found in their normal terminal fields (see below). Where we could unambiguously identify the structure that formed the free end of a sprout (i.e., it was located deep within a section, and not cut on its way to adjacent sections), it consisted of either a varicosity, or a fine, unexpanded free sprout. Terminal-like plexuses did not occur uniformly over all the interface, but tended to cluster in "hot spots" (arrows in Figs. $6 B, C ; 11 B$ ).

Morphological differences between the terminations of the descending and ascending axons were reflected in their responses to Schwann cell grafts. Thus, the ascending dorsal column axons tended to have more branches, at wider angles, and larger ar- 
borizations, and varicose dichotomous terminal branches, as seen in the terminal field in the dorsal horn (compare Fig. $1 C$ with Figs. $8 D, E$ and $11 C, D)$. In contrast, the descending corticospinal axons were much finer, and formed masses of tight curls (e.g., Figs. $6 B, C ; 9 C$ ) with tiny presynaptic bouton-like varicosities that resemble the normal corticospinal arborizations in the medial spinal gray matter (Figs. $1 A, 10$ ).

At longer survivals (Fig. 12A,B), a reduced number of fine tortuous axonal segments were still present, and the axons retained their varicosities. Unlike the long-term lesioned material (Fig. $4 B, C$ ), the varicosities remained spaced singly on the axons. In some cases the islands of surviving Schwann cells were surrounded by looped varicose axons (Fig. 12C-E). Branches, however, were rarely seen after about 2 weeks. This may be due to retraction; alternatively, the axons may have elongated, and the branches extended into and through the adjacent normal segments of the tract, so that the branch points would have become dispersed and difficult to find among the normal parallel host fibers.

\section{Discussion}

In comparison with previous reports of peripheral nerve or cultured Schwann cell grafts into the spinal cord, the main differences in the present study were (1) a microlesion/microtransplantation technique that caused minimal disturbance to the host tract architecture, and (2) an orthograde tracing technique that was able to detect the fine morphological details of the responses of both cut and uncut host axons. As a result we were able to show (1) that corticospinal as well as ascending dorsal column axons respond to contact with Schwann cells, (2) that even without Schwann cells, the lesion is stimulatory for axon sprouting, and (3) that considerable numbers of cut axons persist, without retraction, at the level of the lesion.

\section{Lesions}

Initially the lesions produced swellings at the cut axon tips, and also en passant in cut and uncut axons (Fig. 13A). After about 2 weeks (Fig. 13C), the uncut axons adjacent to the lesion had produced clusters of large contiguous varicosities, and the ends of the cut axons had given rise to exuberant local sprouting, which was confined to the region of the cut ends, and showed no sign of gaining access to the distal, undamaged regions of the host tracts. On the other hand, the greatly increased area of surface membrane provided by the luxuriant local terminal sprouting at the lesion site could provide an important expansion of surface receptors for growth factors. This suggests that the cut axons could go on to further regeneration if they could be provided with the appropriate stimuli and guidance.

Both the long-term persistence of cut axons at the lesion site and their profuse local sprouting responses were unexpected. Although it is well established that the cells of origin of the corticospinal tract and the ascending dorsal columns are not killed by axotomy at the spinal level (Lieberman, 1971; Kalil and Schneider, 1975; Lahr and Stelzner, 1990; Merline and Kalil, 1990), it has been reported that cut axons undergo retrograde degeneration (Kalil and Schneider, 1975), and retract from knife-cut lesions (Lahr and Stelzner, 1990; Firkins et al., 1993). Apart from the major disorganization at such lesion sites, the axon tracing methods used in these studies would not have been optimal for detecting the responses at the cut ends of the axons. Our observations based on our relatively atraumatic microlesion/microtransplant approach, combined with a morpho-
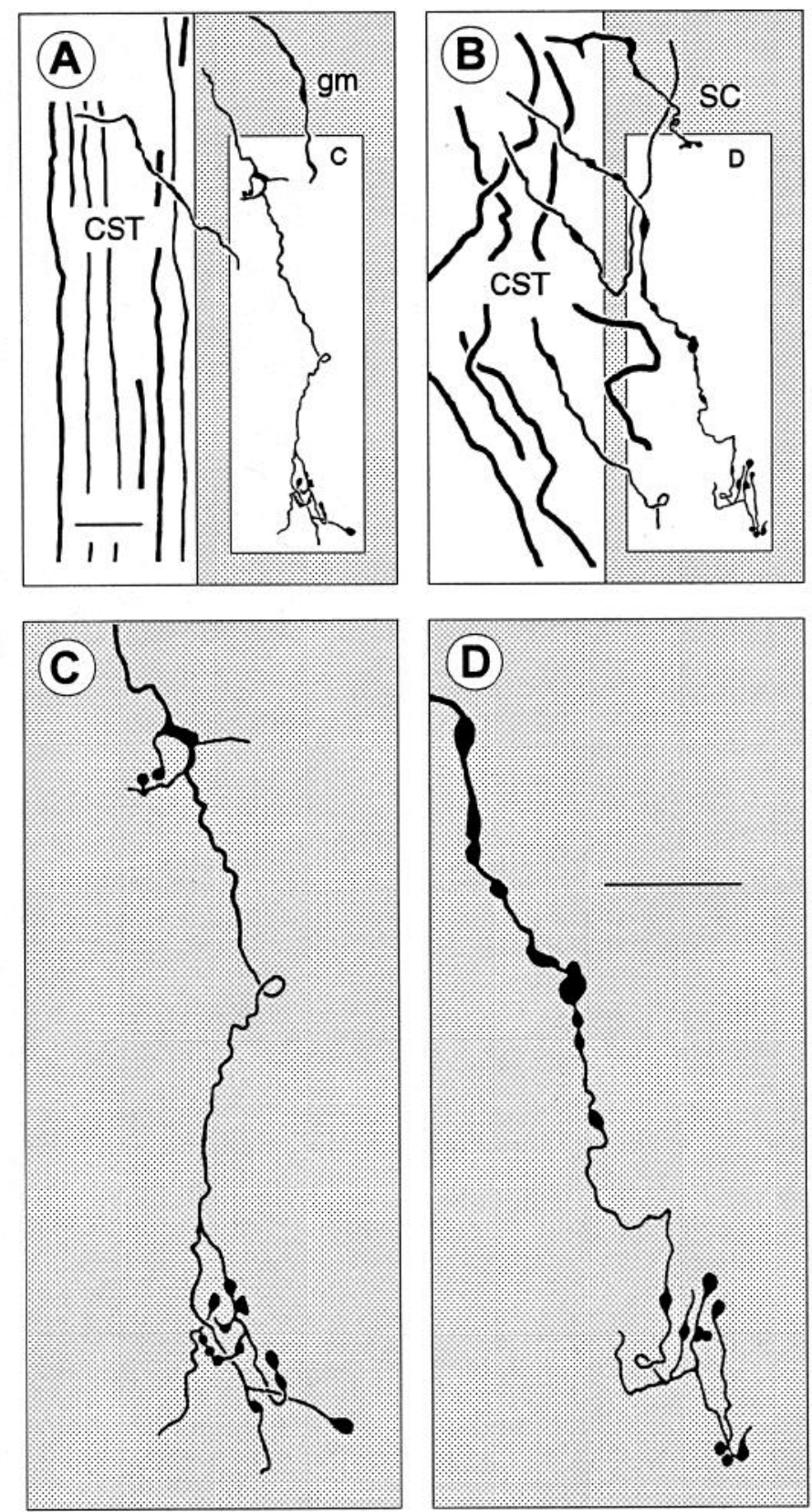

Figure 10. Comparison of the mode of branching of a normal CST axon terminating in the medial part of the spinal gray matter adjacent to the CST (box in $A$, enlarged in $C$ ) with the terminal-like branching of a CST axon (box in $B$, enlarged in $D$ ) entering a Schwann cell graft (shown at low power in Fig. $6 \mathrm{C}$ ) at $8 \mathrm{~d}$ po. Both axons narrow into branched terminal segments bearing en passant or terminal varicosities. Note the disorganization of the CST axons in the grafted material $(B)$ compared with the normal parallel tract $(A)$. Scale bars, $25 \mu \mathrm{m}$.

logically more sensitive orthograde axonal label, show that cut axons persist at the lesion site in considerable numbers, such that if they were able to regenerate, this would seem sufficient to provide a very worthwhile degree of functional recovery.

\section{Schwann cells}

Branching (see also Paino and Bunge, 1991) and the formation of terminal field-like plexuses were the most characteristic effects of our Schwann cell transplants. Compared with the lesions, the 

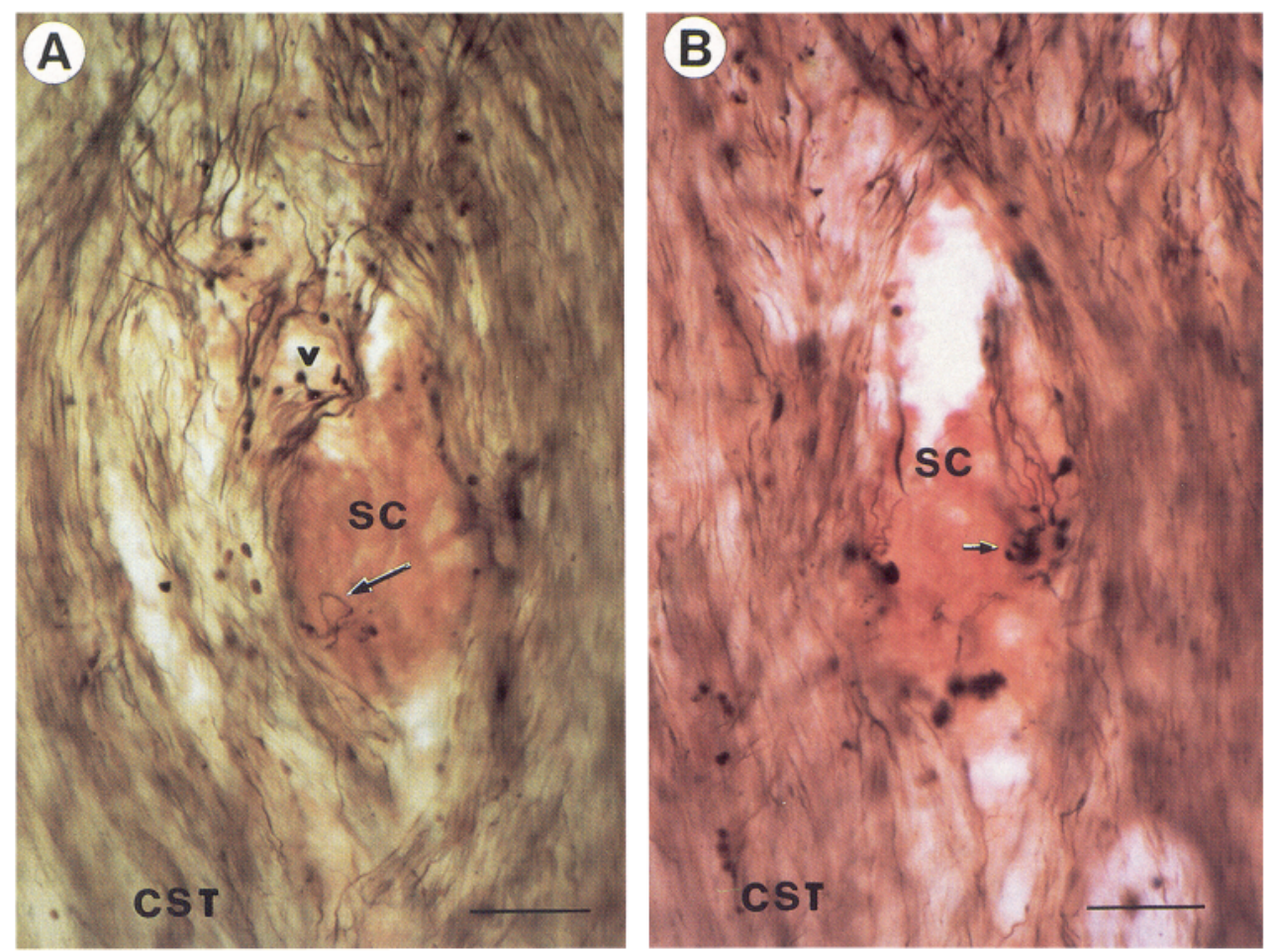

Figure 11. A, Varicosities (v) and a superficial loop (arrow) into a small Schwann cell graft in the CST at $6 \mathrm{~d}$ po. $B$, Schwann cell graft with a hot spot (arrow) containing a knot-like mass of tortuous segments (camera lucida drawing shown in Fig. $6 B$ ) at $5 \mathrm{~d}$ po. $C$, A Schwann cell graft adjacent to a region of uncut axons in the ascending DC (asterisks) at $6 \mathrm{~d}$ po. $D$, Enlarged view (from $C$ ) of a bundle of widely angled axons crossing the entire rostrocaudal extent of the SC graft (arrows). Scale bars: $A, B$, and $D, 50 \mu \mathrm{m} ; C, 100$ $\mu \mathrm{m}$.
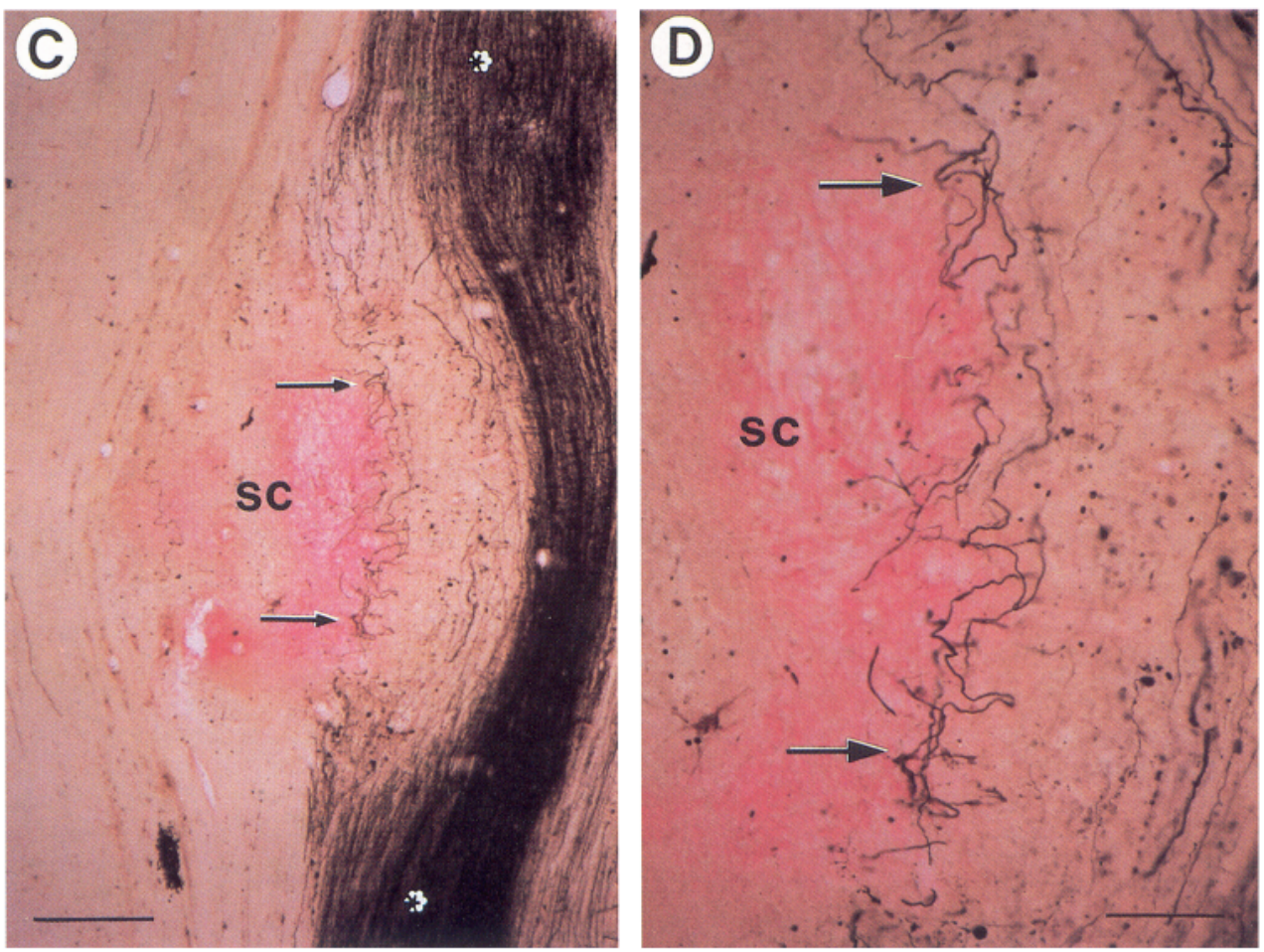

Schwann cell effects were much more rapid in both descending and ascending tracts, and the sprouts much longer (Fig. 13B). The Schwann cell grafts induced far greater and more persistent tortuosity of the uncut host axons, and the surface of the Schwann cell grafts was invaginated by an abundance of very thin axon segments that could be either straight or give rise to masses of densely curled fibers with tiny en passant or terminal spherical expansions, which resembled presynaptic boutons (although there was no indication of any tissue element providing a postsynaptic structure). In many cases the branches passed through knot-like convolutions, but ultimately extended in parallel with existing tract axons and fasciculated with them. The reduced incidence of these structures in the longer-term Schwann cell transplants may have been due to maturation and elongation of the branches, although we cannot exclude that they may have retracted.

One of the main questions still unanswered is whether, when compared with the lesioned animals, the more rapid and exuberant sprouting in the Schwann cell transplants is due specif- 

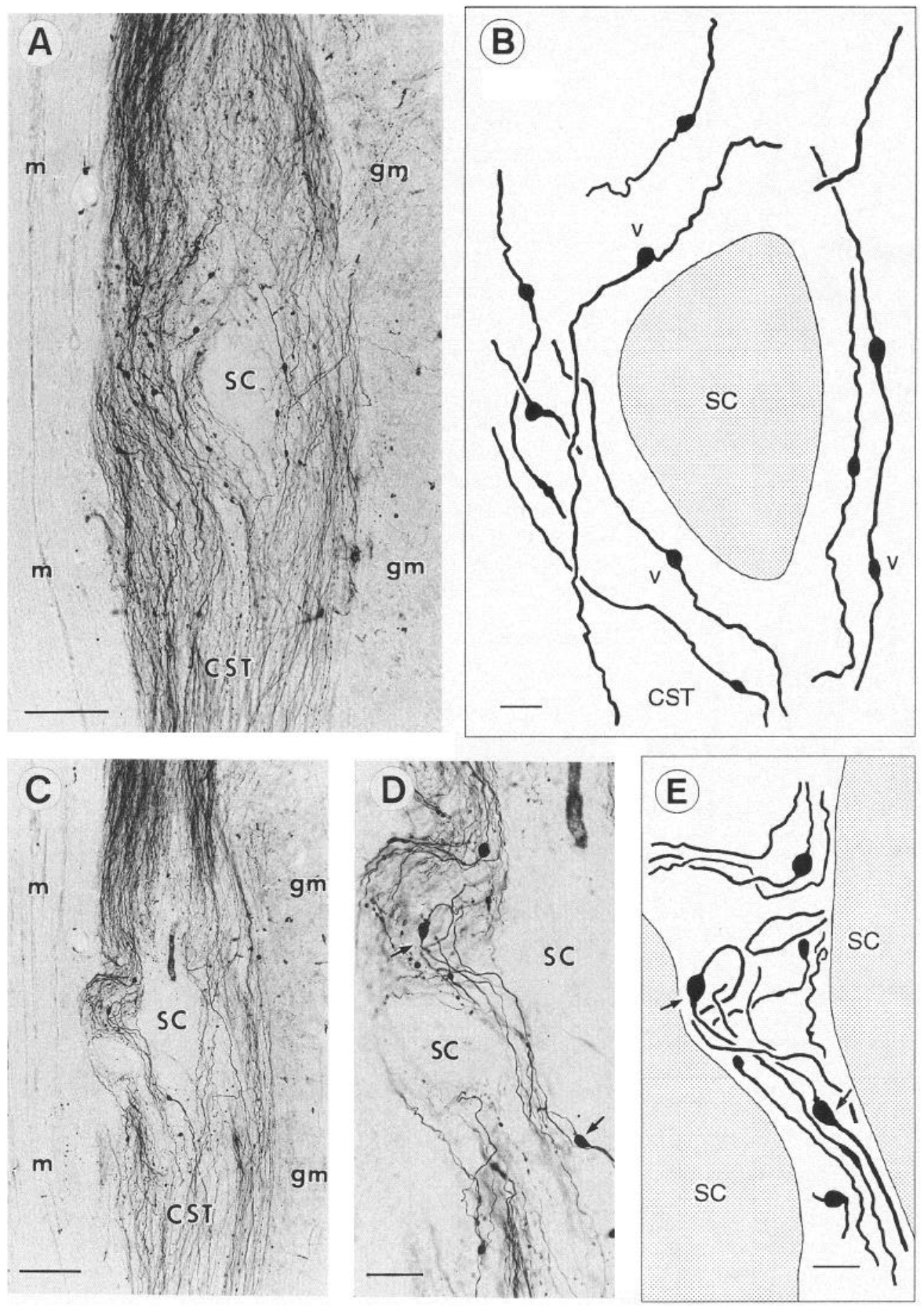

Figure 12. Photomicrograph $(A)$ and camera lucida drawing $(B)$ of a longterm (21 d) Schwann cell graft surrounded by axon varicosities $(v)$ in the CST, and photomicrographs $(C, D)$ and camera lucida drawing $(E)$ of a longterm $(21$ d) Schwann cell graft surrounded by looping varicose CST axons (arrows in $D$ and $E$ ). Scale bars: $A, C$, $100 \mu \mathrm{m} ; D, 50 \mu \mathrm{m} ; B, E, 25 \mu \mathrm{m}$. ically to influences arising from the Schwann cells rather than the much less traumatic approach. Thus, the electrolytic lesions caused much more complete tissue destruction, including glia as well as probably many more axons, and leading to massive infiltration of the necrotic areas by macrophages. We are currently investigating this question using Schwann cell transplants into electrolytic lesion areas, and injections of suspensions of control, non-Schwann cells.

Several authors, using both peripheral nerve grafts (Richardson et al., 1982, 1984) and transplantation of cultured Schwann cells (Kuhlengel et al., 1990b; Martin et al., 1991, 1993), have detected a sprouting response in the ascending dorsal column branches of the centrally projecting axons of the dorsal root ganglion cells by either retrograde cell labeling (Richardson et al., 1982, 1984; Kuhlengel et al., 1990b) or immunohistochemistry (Martin et al., 1991, 1993). Despite the reported difficulty in recruiting corticospinal axons into peripheral nerve grafts at the spinal level (Richardson et al., 1982, 1984), our morphologically more sensitive orthograde HRP labeling technique clearly showed that corticospinal axons can also respond to intraspinal Schwann cell grafts, although perhaps they are unable to extend sufficiently along peripheral nerve grafts to be detected by retrograde tracers applied at some distance from the graft site. 


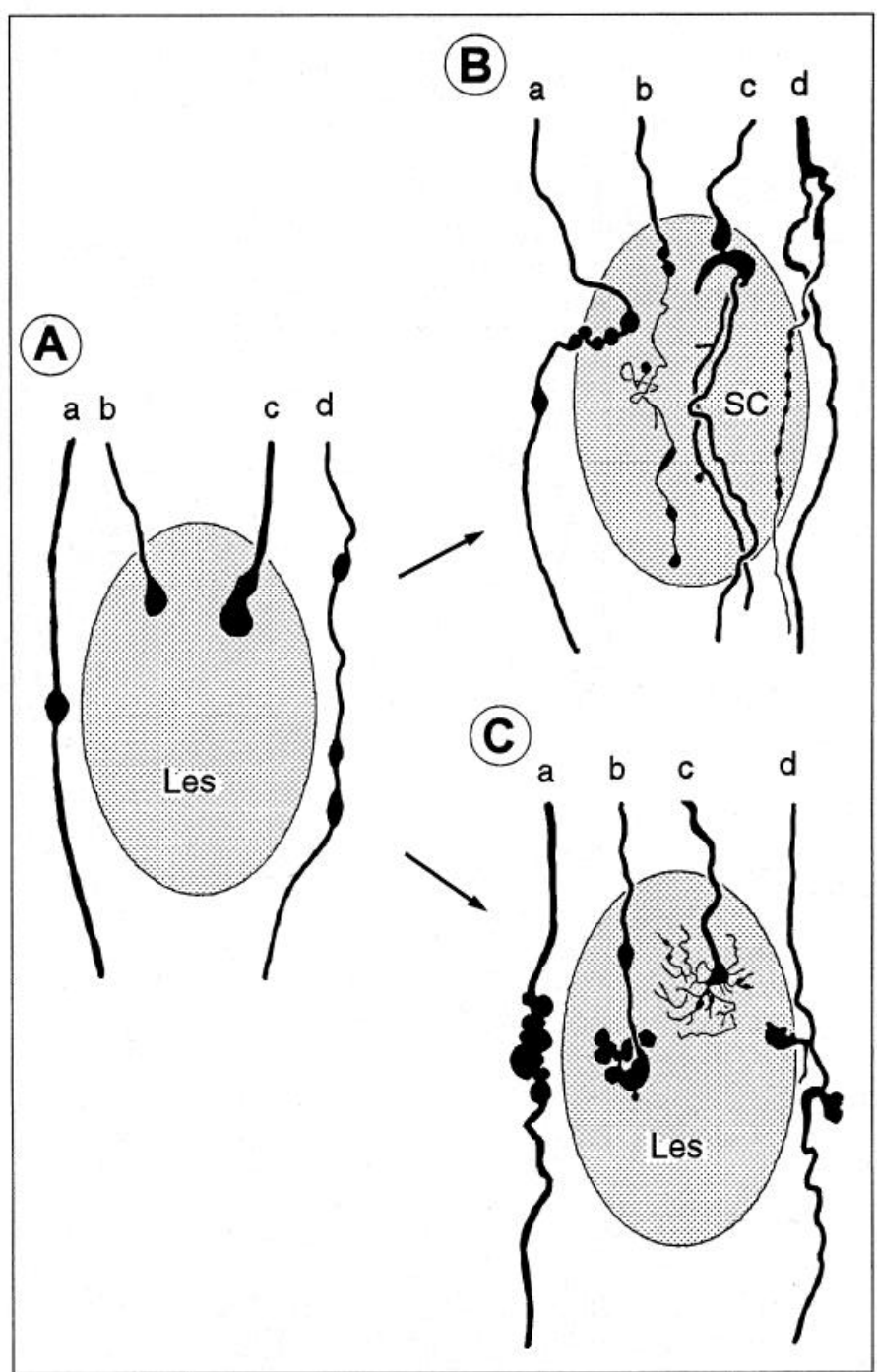

Figure 13. Schematic diagram showing our conclusions of the comparison of the effects of a lesion $(A)$ treated by transplanting Schwann cells $(B)$, or neglected $(C)$. In both situations, both cut $(b, c)$ and uncut $(a, d)$ axons respond by sprouting, but in the Schwann cell area, the sprouts take up a longitudinal orientation, fasciculating with other axons (and probably regaining access to the host astrocytic longitudinal framework of the tract), whereas in the absence of Schwann cells $(C)$ the cut ends are unable to advance, and the exuberant local expansions of cut and uncut axons are confined to the lesion area. The diagram uses axonal configurations adapted from the main set of 'llustrations.

\section{Mechanism}

The stimulatory effects of transplanted peripheral nerve or cultured Schwann cells on cut central axons are well established (references above). The stimulatory effects of lesions (as also noted by Ramon y Cajal, 1928) may be due to a number of factors, such as damage to astrocytes, oligodendrocytes, demyelination, the presence of degeneration products, or the invasion of macrophages. Damage to the axon itself may be a stimulatory factor for cut axons, but our observations suggest that both Schwann cells and lesions were also powerful stimuli for the sprouting of uncut axons.

Compared with the descending axons, the more exuberant sprouting that Schwann cell transplants induced in the ascending axons may be partly due to their larger diameter (and/or the proximity to the cell bodies). On the other hand, it should be remembered that, whereas corticospinal axons never normally come into contact with Schwann cells, the ascending dorsal column sensory fibers are the central branches of dorsal root ganglion cells that are normally apposed by Schwann cells along their entire peripheral branches, their cell bodies, and the first parts of their centrally directed branches in the dorsal roots. It would not therefore be unexpected if their cut central branches were particularly responsive to contact with Schwann cells.

Schwann cells are known to secrete a number of growth factors that act on neurons (e.g., Bandtlow et al., 1987; Leibrock et al., 1989; Meyer et al., 1992; Neuberger and De Vries, 1993), and these would presumably be part of the mechanism of the sprouting we have observed in the present experiments. Despite the overlapping specificity in growth factors and their receptors (for a review, see Korsching, 1993), different types of nerve cells do show cell type-specific differences. Although it has been reported that peripheral nerve grafts may be selective for particular types of axons (Richardson et al., 1982, 1984; Benfey et al., 1985; Morrow et al., 1993), our present observations show that both descending corticospinal and ascending dorsal column axons respond to injections of Schwann cells.

\section{References}

Bandtlow CE, Heumann R, Schwab ME, Thoenen H (1987) Cellular localization of nerve growth factor synthesis by in situ hybridization. EMBO J 6:891-899.

Benfey M, Bunger UR, Vidal-Sanz M, Bray GM, Aguayo AJ (1985) Axonal regeneration from GABAergic neurons in the adult rat thalamus. J Neurocytol 14:279-296.

Berry M, Hall SF, Rees L, Gregson N, Sievers J (1988a) Response of axons and glia at the site of anastomosis between the optic nerve and cellular or acellular sciatic nerve grafts. J Neurocytol 17:727-744.

Berry M, Rees L, Hall S, Yiu P, Sievers J (1988b) Optic axons regenerate into sciatic nerve isografts only in the presence of Schwann cells. Brain Res Bull 20:223-231.

Brockes JP, Fields KL, Raff MC (1979) Studies on cultured rat Schwann cells. I. Establishment of purified populations from cultures of peripheral nerve. Brain Res 165:105-118.

Brook GA, Lawrence JM, Raisman G (1993) Morphology and migration of cultured Schwann cells transplanted into the fimbria and hippocampus in adult rats. Glia 9:292-304.

Campbell G, Lieberman AR, Anderson PN, Turmaine M (1992) Regeneration of adult rat CNS axons into peripheral nerve autografts: ultrastructural studies of the early stages of axonal sprouting and regenerative axonal growth. J Neurocytol 21:755-787.

Carter DA, Bray GM, Aguayo AJ (1989) Regenerated retinal ganglion cell axons can form well-differentiated synapses in the superior colliculus of adult hamsters. J Neurosci 9:4042-4050.

Davies SJA, Field PM, Raisman G (1993) Long fibre growth by axons of embryonic mouse hippocampal neurons micro-transplanted into the adult rat fimbria. Eur J Neurosci 5:95-106.

Davies SJA, Field PM, Raisman G (1994) Long interfascicular axon growth from embryonic neurons transplanted into adult myelinated tracts. J Neurosci 14:1596-1612.

Emmett CJ, Jaques-Berg W, Seeley PJ (1990) Microtransplantation of neural cells into adult rat brain. Neuroscience 38:213-222.

Firkins SS, Bates CA, Stelzner DJ (1993) Corticospinal tract plasticity and astroglial reactivity after cervical spinal injury in the postnatal rat. Exp Neurol 120:1-15.

Hagg T, Gulati AK, Behzadian MA, Vahlsing HL, Varon S, Manthorpe M (1991) Nerve growth factor promotes CNS cholinergic axonal regeneration into acellular peripheral nerve grafts. Exp Neurol 112: 79-88.

Itoh K, Konishi A, Nomura S, Mizuno N, Nakamura Y, Sugimoto T (1979) Application of coupled oxidation reaction to electron microscopic demonstration of horseradish peroxidase: cobalt-glucose oxidase method. Brain Res 175:341-346.

Kalil K, Schneider GE (1975) Retrograde cortical and axonal changes following lesions of the pyramidal tract. Brain Res 89:15-27. 
Keirstead SA, Rasminsky M, Fukuda Y, Carter DA, Aguayo AJ, VidalSanz M (1989) Electrophysiologic responses in hamster superior colliculus evoked by regenerating retinal axons. Science 246:255-256.

Knoops B, Ponsar C, Hubert I, Van Den Bosch De Aguilar P (1993) Axonal regeneration after peripheral nerve grafting and fibrin-fibronectin-containing matrix implantation on the injured septohippocampal pathway of the adult rat: a light and electron microscopic study. Restor Neurol Neurosci 5:103-117.

Korsching S (1993) The neurotrophic factor concept: a reexamination. J Neurosci 13:2739-2748.

Kromer LF, Cornbrooks CJ (1985) Transplants of Schwann cell cultures promote axonal regeneration in the adult mammalian brain. Proc Natl Acad Sci USA 82:6330-6334.

Kuhlengel KR, Bunge MB, Bunge RP (1990a) Implantation of cultured sensory neurons and Schwann cells into lesioned neonatal rat spinal cord. I. Methods for preparing implants from dissociated cells. J Comp Neurol 293:63-73.

Kuhlengel KR, Bunge MB, Bunge RP, Burton $\mathrm{H}$ (1990b) Implantation of cultured sensory neurons and Schwann cells into lesioned neonatal rat spinal cord. II. Implant characteristics and examination of corticospinal tract growth. J Comp Neurol 293:74-91.

Lahr SP, Stelzner DJ (1990) Anatomical studies of dorsal column axons and dorsal root ganglion cells after spinal cord injury in the newborn rat. J Comp Neurol 293:377-398.

Leibrock J, Lottspeich F, Hohn A, Hofer M, Hengerer B, Masiakowski P, Thoenen H, Barde YA (1989) Molecular cloning and expression of brain-derived neurotrophic factor. Nature 341:149-152.

Li Y, Raisman G (1993) Long interfascicular axon growth from embryonic mouse hippocampal neurons transplanted into the myelinated corticospinal tracts and dorsal columns of immunosuppressed adult rat hosts. Brain Res 629:115-127.

Lieberman AR (1971) The axon reaction: a review of the principal features of perikaryal responses to axon injury. Int Rev Neurobiol 14:49-124.

Lund RD, Chang FLF, Hankin MH, Lagenaur CF (1985) Use of a species-specific antibody for demonstrating mouse neurons transplanted to rat brains. Neurosei Lett 61:221-226.

Martin D, Schoenen J, Delrée P, Leprince P, Rogister B, Moonen G (1991) Grafts of syngeneic cultured, adult dorsal root ganglion-derived Schwann cells to the injured spinal cord of adult rats: preliminary morphological studies. Neurosci Lett 124:44-48.

Martin D, Schoenen J, Delree P, Rigo J-M, Rogister B, Leprince P, Moonen G (1993) Syngeneic grafting of adult rat DRG-derived Schwann cells to the injured spinal cord. Brain Res Bull 30:507-514.

Merline M, Kalil K (1990) Cell death of corticospinal neurons is induced by axotomy before but not after innervation of spinal targets. J Comp Neurol 296:506-516.

Meyer M, Matsuoka I, Wetmore C, Olson L, Thoenen H (1992) Enhanced synthesis of brain-derived neurotrophic factor in the lesioned peripheral nerve: different mechanisms are responsible for the regulation of BDNF and NGF mRNA. J Cell Biol 119:45-55.

Montero-Menei CN, Pouplard-Barthelaix A, Gumpel M, Baron-Van Evercooren A (1992) Pure Schwann cell suspension grafts promote regeneration of the lesioned septo-hippocampal cholinergic pathway. Brain Res 570:198-208.

Morrow DR, Campbell G, Lieberman AR, Anderson PN (1993) Differential regenerative growth of CNS axons into tibial and peroneal nerve grafts in the thalamus of adult rats. Exp Neurol 120:60-69.

Neuberger TJ, De Vries GH (1993) Distribution of fibroblast growth factor in cultured dorsal root ganglion neurons and Schwann cells. I. Localization during maturation in vitro. J Neurocytol 22:436-448.

Neuberger TJ, Cornbrooks CJ, Kromer LF (1992) Effects of delayed transplantation of cultured Schwann cells on axonal regeneration from central nervous system cholinergic neurons. J Comp Neurol 315:1633.

Paino CL, Bunge MB (1991) Induction of axon growth into Schwann cell implants into lesioned adult rat spinal cord. Exp Neurol 114:254257.

Palmgren A (1960) Specific silver staining of nerve fibres. Acta Zool 41:239-265.

Ramon y Cajal S (1928) Degeneration and regeneration of the nervous system. New York: Hafner.

Reier PJ (1986) Gliosis following CNS injury: the anatomy of astrocytic scars and their influences on axonal elongation. In: Astrocytes, Vol 3 (FedoroffS, Vernadakis A, eds), pp 163-196. New York: Raven.

Richardson PM, McGuinness UM, Aguayo AJ (1982) Peripheral nerve autografts to the rat spinal cord: studies with axonal tracing methods. Brain Res 237:147-162.

Richardson PM, Issa VMK, Aguayo AJ (1984) Regeneration of long spinal axons in the rat. J Neurocytol 13:165-182.

Schnell L, Schwab ME (1993) Sprouting and regeneration of lesioned corticospinal tract fibres in the adult rat spinal cord. Eur J Neurosci 5:1156-1171.

Schwab ME, Kapfhammer JP, Bandtlow CE (1993) Inhibitors of neurite growth. Annu Rev Neurosci 16:565-595.

Smith GV, Stevenson JA (1988) Peripheral nerve grafts lacking viable Schwann cells fail to support central nervous system axonal regeneration. Exp Brain Res 69:299-306.

Suzuki M, Raisman G (1992) The glial framework of central white matter tracts: segmented rows of contiguous interfascicular oligodendrocytes and solitary astrocytes give rise to a continuous meshwork of transverse and longitudinal processes in the adult rat fimbria. Glia $6: 222-235$.

Thanos S (1992) Adult retinofugal axons regenerating through peripheral nerve grafts can restore the light-induced pupilloconstriction reflex. Eur J Neurosci 4:691-699.

Tomatsuri M, Okajima S, Ide C (1993) Sprout formation at nodes of Ranvier of crush-injured peripheral nerves. Restor Neurol Neurosci 5:275-282.

Vidal-Sanz M, Bray GM, Villegas-Pérez MP, Thanos S, Aguayo AJ (1987) Axonal regeneration and synapse formation in the superior colliculus by retinal ganglion cells in the adult rat. J Neurosci 7:28942909 .

Vidal-Sanz M, Bray GM, Aguayo AJ (1991) Regenerated synapses persist in the superior colliculus after the regrowth of retinal ganglion cell axons. J Neurocytol 20:940-952.

Wictorin K, Björklund A (1992) Axon outgrowth from grafts of human embryonic spinal cord in the lesioned adult rat spinal cord. Neuroreport 3:1045-1048.

Wictorin K, Brundin P, Gustavii B, Lindvall O, Björklund A (1990a) Reformation of long axon pathways in adult rat central nervous system by human forebrain neuroblasts. Nature 347:556-558.

Wictorin K, Clarke DJ, Bolam P, Björklund A (1990b) Fetal striatal neurons grafted into the ibotenate lesioned adult striatum: efferent projections and synaptic contacts in the host globus pallidus. Neuroscience 37:301-316.

Wictorin K, I agenaur CF, I und RD, Björklund A (1991) Efferent projections to the host brain from intrastriatal striatal mouse-to-rat grafts: time course and tissue-type specificity as revealed by a mouse specific neuronal marker. Eur J Neurosci 3:86 101.

Wictorin K, Brundin P, Sauer H, Lindvall O, Björklund A (1992) Long distance directed axonal growth from human dopaminergic mesencephalic neuroblasts implanted along the nigrostriatal pathway in 6-hydroxydopamine lesioned adult rats. J Comp Neurol 323:475494.

Wrathall JR, Kapoor V, Kao CC (1984) Observation of cultured peripheral non-neuronal cells implanted into the transected spinal cord. Acta Neuropathol (Berl) 64:203-212.

Zwimpfer TJ, Aguayo AJ, Bray GM (1992) Synapse formation and preferential distribution in the granule cell layer by regenerating retinal ganglion cell axons guided to the cerebellum of adult hamsters. $J$ Neurosci 12:1144-1159. 